\title{
The Effects of Prior Language Knowledge in Japanese Acquisition as a Foreign Language: The Case of the Japanese Noun Modifier No
}

Sally Chan

The University of New South Wales

\begin{abstract}
The misuse of the Japanese noun modifier no has been observed over decades. Recent research investigating learners of Japanese as a foreign language with Chinese as their first language (L1) presented evidence of negative language transfer. This study aims to replicate the findings of a quantitative study conducted in Japan that investigated the misuse of no through assessing Chinese, Korean and English L1 learners of Japanese who reside in Sydney, Australia. These learners were tested in both instantaneous production and production with no time restriction. Given that the Chinese language contains a corresponding noun modifier 的 (de), the results showed a significant negative language transfer in the Chinese L1 group. This and other results will be discussed.
\end{abstract}

\section{Keywords}

foreign language acquisition; negative language transfer; noun modifier no; prior language knowledge

To link to this article: http://dx.doi.org/10.21159/nv.06.02 


\section{Introduction}

The ability to acquire new languages is affected by an individual's past language knowledge and experiences. ${ }^{1}$ Speakers of Chinese, Korean and English as their first language constitute approximately $57 \%$ of Japanese language learners across the world. ${ }^{2}$ Much literature has examined the effects of these three languages on the acquisition of Japanese, particularly from the perspective of language transfer. ${ }^{3}$

Language transfer is the effect of any knowledge of the learner's first language or other prior language knowledge (Lp) that has been 'transferred' or applied by the learner, either consciously or subconsciously, in the acquisition and/or in the construction process of the target language (TL). ${ }^{4}$ Of the two main types of language transfer, negative language transfer is the production of unusual or 'un-native-like' forms of the target language of which may resemble other already acquired language(s). For example, there are reported observations of the misuse of the Japanese term 生きる (ikiru; to live (the state of being alive)) for 住む (sumu; to live (to reside at a location)) by English first-language (L1) learners; ' for example, ‘シドニーに生きている’ (Shidonii ni ikiteiru; literally, 'I am alive in Sydney'). ${ }^{6}$ This is a result of negative language transfer from English to Japanese, where the English 'to live' has a wider semantic field than the Japanese 'ikiru'.

This study aims to replicate a study conducted in Japan by Okuno, ${ }^{7}$ which investigated the misuse of the Japanese noun modifier no by Chinese, Korean and English L1 speakers. By examining a sample of Japanese learners residing in Sydney, Australia, this study confirms that negative language transfer is the process underlying this misuse.

This article will first review past research related to the Japanese noun modifier no, and outline the research methodology. The results will then be presented and examined in light of negative language transfer, followed by a discussion of the limitations of this study. Lastly, the study will be summarised in the concluding section with reference to some directions for future research.

Ellis, The Study of Second Language Acquisition (2nd ed.).

The Japan Foundation, Survey Report on Japanese-language Education Abroad 2009.

For example: Koyama, 'Rentai shūshoku kōzō'; Okuno, Dai ni gengo shūtoku; Peng, Gaikokujin wo nayamaseru nihongo; Sakoda, 'Dai ni gengo shūtoku';

Shirahata, 'Seijin dai ni gengo'; Shirahata, 'Rentai shūshoku kōzō'; Shirahata, 'Yōji no dai ni gengo.'

Odlin, Language Transfer.

Learners of Japanese with English as first language (English L1 learners); learners of Japanese with Chinese as first language (Chinese L1 learners);

learners of Japanese with Korean as their first language (Korean L1 learners) and so forth.

6 Peng, op. cit.

7 Okuno, op. cit. 


\section{The Japanese Noun Modifier No}

Evidence of negative language transfer has been found in studies concerning the misuse of the Japanese noun modifier no (の). The Japanese noun modifier no is a particle that indicates ownership, for example, 車包色 (kuruma no iro; the colour of the car), and its usage is restricted to cases following a noun, as shown in Table 1.

Table 1. Examples of the Uses of the Japanese No

\begin{tabular}{|c|c|c|c|c|}
\hline & $\begin{array}{l}\text { Noun-modifying } \\
\text { phrase }\end{array}$ & $\begin{array}{l}\text { True adjective } \\
\text { phrase }\end{array}$ & $\begin{array}{l}\text { Noun-adjective } \\
\text { phrase }\end{array}$ & Verbal phrase \\
\hline Japanese & $\begin{array}{l}\text { 車の色は赤です。 } \\
\text { Kuruma no iro wa } \\
\text { aka desu. }\end{array}$ & $\begin{array}{l}\text { 小さい犬 は可愛 } \\
\text { いです。 } \\
\text { Chiisai inu wa } \\
\text { kawaii desu. }\end{array}$ & $\begin{array}{l}\text { そのきれいな人 } \\
\text { は先生です。 } \\
\text { Sono kirei na hito } \\
\text { wa sensei desu. } \\
\end{array}$ & $\begin{array}{l}\text { 葠ている猫は } \\
\text { ブーちゃんです。 } \\
\text { Neteiru neko wa } \\
\text { buuchan desu. }\end{array}$ \\
\hline $\begin{array}{l}\text { English } \\
\text { translation }\end{array}$ & $\begin{array}{l}\text { The colour of the } \\
\text { car is red. }\end{array}$ & $\begin{array}{l}\text { Small dogs } \\
\text { are cute. }\end{array}$ & $\begin{array}{l}\text { The beautiful } \\
\text { person there is } \\
\text { the teacher. }\end{array}$ & $\begin{array}{l}\text { The cat which } \\
\text { is sleeping is } \\
\text { Bu-chan. }\end{array}$ \\
\hline
\end{tabular}

However, its misuse has often been observed. ${ }^{8}$ There are four main misuse categories in relation to this noun modifier, as shown in Table $2 .^{9}$

Table 2. Four Categories of Misuse Related to the Noun Modifier No

\begin{tabular}{|l|l|l|l|l|}
\hline & $\begin{array}{l}\text { Noun-modifying } \\
\text { phrase }\end{array}$ & $\begin{array}{l}\text { True adjective } \\
\text { phrase }\end{array}$ & $\begin{array}{l}\text { Noun-adjective } \\
\text { phrase }\end{array}$ & Verbal phrase \\
\hline $\begin{array}{l}\text { Observed } \\
\text { misuse }\end{array}$ & $\begin{array}{l}\text { 車色は赤です。 } \\
\text { Kuruma iro wa } \\
\text { aka desu. }\end{array}$ & $\begin{array}{l}\text { 小さいの犬 は可 } \\
\begin{array}{l}\text { 愛いです。 } \\
\text { Chiisai no } \text { inu wa } \\
\text { kawaii desu. }\end{array}\end{array}$ & $\begin{array}{l}\text { そのきれいの人 } \\
\text { は先生です。 } \\
\text { Sono kirei no hito } \\
\text { wa sensei desu. }\end{array}$ & $\begin{array}{l}\text { 誛でーちの猫は } \\
\text { Neteiru no neko } \\
\text { wa buuchan desu. }\end{array}$ \\
\hline $\begin{array}{l}\text { English } \\
\text { translation }\end{array}$ & $\begin{array}{l}\text { The colour the car } \\
\text { is red. }\end{array}$ & $\begin{array}{l}\text { Small dogs' are } \\
\text { cute. }\end{array}$ & $\begin{array}{l}\text { The beautiful's } \\
\text { person there is the } \\
\text { teacher. }\end{array}$ & $\begin{array}{l}\text { The cat which } \\
\text { is of sleeping is } \\
\text { Bu-chan. }\end{array}$ \\
\hline
\end{tabular}

In the case of noun precedence, the no is observed to have been omitted, whereas in the case of the true adjective and verbal phrase, the particle no was observed to have

\footnotetext{
8 Clancy, 'The Acquisition of Japanese'; Okuno, op. cit..; Sakoda, op. cit.; Shirahata, 'Seijin dai ni gengo'; Shirahata, 'Rentai shūshoku kōzō'; Shirahata, 'Yōji no dai ni gengo.'

9 English translations have been provided to give a rough equivalent of the misuse.
} 
been inappropriately added. Lastly, in the case of the noun-adjective, no has been observed to replace na (な).

The above misuses have been observed in conversation data amongst learners of Japanese from different first-language backgrounds, such as Korean, Chinese, English, Malaysian and Thai, as well as among children acquiring Japanese as their first language, ${ }^{10}$ which is suggested to be a developmental error. ${ }^{11}$ Taking Japanese-language proficiency into consideration, a meta-analysis of conversation data revealed a bell-curve trend in the number of observed misuses. The number peaks around the intermediate proficiency level, begins to decline as learners reach the advanced level, and falls close to zero at the professional (superior) level of proficiency. ${ }^{12}$ However, Sakoda reports an exception. ${ }^{13}$ Chinese L1 learners have demonstrated the misuse even at stages of advanced and professional proficiency. This is attributed to 'interference', or the negative language transfer of prior language knowledge of the Chinese character 的 (de), which carries an equivalent meaning to that of the Japanese noun modifier no but differs in usage (see Table 3).

Table 3. Examples of the Equivalent of the Noun Modifier No for Different Languages ${ }^{14}$

\begin{tabular}{|l|l|l|l|l|}
\hline Language & $\begin{array}{l}\text { Noun-modifying } \\
\text { phrase }\end{array}$ & $\begin{array}{l}\text { True adjective } \\
\text { phrase }\end{array}$ & $\begin{array}{l}\text { Noun-adjective } \\
\text { phrase }\end{array}$ & Verbal phrase \\
\hline Japanese & $\begin{array}{l}\text { 車の色 } \\
\text { Kuruma no iro }\end{array}$ & $\begin{array}{l}\text { 小さい犬 } \\
\text { Chiisai inu }\end{array}$ & $\begin{array}{l}\text { きれいな人 } \\
\text { Kirei na hito }\end{array}$ & $\begin{array}{l}\text { 寝ている猫 } \\
\text { Neteiru neko }\end{array}$ \\
\hline Chinese & $\begin{array}{l}\text { 车的颜色 } \\
\text { Che de yanse }\end{array}$ & $\begin{array}{l}\text { 很小的狗 } \\
\text { Hen xiao de gou }\end{array}$ & $\begin{array}{l}\text { 美丽的人 } \\
\text { Mei li de ren }\end{array}$ & $\begin{array}{l}\text { 在睡的猫 } \\
\text { Zai shui de mao }\end{array}$ \\
\hline Korean & $\begin{array}{l}\text { 자동차(의)색상 } \\
\text { Ja-dong-cha }(u i) \\
\text { saek-ssang }\end{array}$ & $\begin{array}{l}\text { 작은 개 } \\
\text { Ja-geun gae }\end{array}$ & $\begin{array}{l}\text { 예븐 사람 } \\
\text { Ye-ppeun sa-ram }\end{array}$ & $\begin{array}{l}\text { 자고있는 고양이 } \\
\text { Ja-go-in-neun go- } \\
\text { yang-i }\end{array}$ \\
\hline English & $\begin{array}{l}\text { The colour of the } \\
\text { car }\end{array}$ & A small dog & A beautiful person & $\begin{array}{l}\text { The cat which is } \\
\text { sleeping OR the } \\
\text { sleeping cat }\end{array}$ \\
\hline
\end{tabular}

10 Clancy, op. cit.; Koyama, op. cit.; Murasugi, Noun Phrase in Japanese and English; Murasugi and Hashimoto, 'Yōji ni mirareru meishiku de no nishurui no kajō seisei'; Nagano, 'Yōji no gengo hattatsu'; Okuno, op. cit.; Sakoda, op. cit.; Shirahata, 'Seijin dai ni gengo'; Shirahata, 'Rentai shūshoku kōzō'; Shirahata, 'Yōji no dai ni gengo'; Yokoyama, 'Yōji no rentai shūshoku.'

11 Developmental errors are 'errors that are normal occurrences in the course of learning either a first or second language' (Odlin, op. cit., p. 166).

12 Koyama, op. cit.; Sakoda, op. cit.

13 Sakoda, op. cit.

14 Based on Okuno, op. cit., p. 91. 
The Chinese de is distinctive from Japanese, Korean and English equivalents in that, in addition to nouns, it can also follow adjectives and verbs. Thus, this conflicting usage between Chinese and Japanese may have delayed or even prevented the successful acquisition and/or production of the correct use of no by Chinese L1 learners. However, Sakoda's results were limited for the following reasons: the results were binary coded (yes or no misuse) and thus the quantitative information was discarded; the study was cross-sectional and therefore changes cannot be tracked over time; and as qualitative research offers limited scope for assessing the significance of data, the results lack convincing empirical evidence.

Inspired by Sakoda's research, two further studies were conducted by Okuno to confirm the effects of negative language transfer of the Chinese de. ${ }^{15}$ The first study was a qualitative longitudinal study where Oral Proficiency Interviews (OPIs) held with professionally trained and qualified OPI assessors were recorded and transcribed to determine Japanese language proficiency and observe misuse in learners' speech. ${ }^{16}$ All subjects (29 in total) were Japanese language learners on exchange in Japan who were L1 speakers of Chinese (11), English (6), Spanish (1), French (1), German (3) and Korean (7). OPIs were held before (pre-course) and after (post-course) university courses at two local universities in Japan. Subjects were ranked across proficiency levels (beginner, intermediate or advanced) and within each level (lower, middle or upper).

The results showed the following:

1. Subjects who were ranked as beginners pre-course (5 Chinese and 2 English L1 learners) did not demonstrate much use of no. After achieving intermediate proficiency, misuse was observed in five of these seven students in post-course OPIs, regardless of their first language.

2. Subjects who were ranked as intermediate pre-course (6 Chinese, 4 English, 1 French, 1 Spanish and 3 German) also demonstrated misuse, regardless of their first language. However, among subjects with advanced proficiency post-course, more Chinese L1 learners demonstrated misuse across the four grammatical categories of misuse identified above.

Similar to Korean and English L1 learners, French, Spanish and German L1 learners used the Japanese no equivalent only after nouns, and in the Spanish and French case, also after verbs. The above results demonstrated trajectories of change in misuse over 
the learners' progress from beginner to advanced proficiency, confirming the results of Sakoda. Furthermore, they provided indication for negative language transfer of Chinese, at least for advanced learners.

To overcome the limitations of the qualitative nature of previous research, Okuno's second study used a quantitative approach ${ }^{17}$ Firstly, OPIs were conducted to determine the Japanese-language proficiency level of 30 university students or graduates with Chinese, Korean and English L1 (10 per group). Negative language transfer was examined using the Instantaneous Response Judgement Test (IRJT) introduced by Okuno. ${ }^{18}$ The IRJT is a listening test comprising manipulated sentences that include both misuses and correct uses of no. It aims to assess the subject's language knowledge at a subliminal level through restricting response time and increasing the cognitive load. ${ }^{19}$ Cognitive load is imposed on the subjects by the need to simultaneously process both audio and visual information to judge the grammaticality of the sentences.

In addition to assessing subliminal knowledge, conscious knowledge was also assessed using a written version of the IRJT, namely, the self-paced Written Test (WT), where the auditory component of the test is removed and sufficient time is given for subjects to complete the test at their own pace. The WT aims to verify that subjects have acquired all relevant language knowledge and ability necessary to identify and correct misuse.

In comparing the performance of Korean and Chinese L1 learners, the Chinese L1 learners demonstrated significant difficulty in recognising misuse in the verbal phrase category of the IRJT. This was despite WT results indicating that both Chinese and Korean learners had the same level of correctly acquired conscious language knowledge of grammar. No difference was found amongst the performance of the Chinese and English L1 groups.

From this, and in line with past studies, ${ }^{20}$ Okuno postulated that the misuse of no emerges as a developmental error at the intermediate level across language groups, similar to that found during first-language acquisition in Japanese children. ${ }^{21}$ Negative language transfer appears to affect Chinese L1 learners as proficiency advances, and only in the verb category. However, there are several limitations to this study. Firstly, empirical evidence from one study is insufficient to suggest negative language transfer as the cause of misuse. Furthermore, negative language transfer should be assessed in consideration

\footnotetext{
17 Okuno, op. cit., p. 96-111.

18 ibid., p. 99.

19 Cognitive load was suggested to increase the dependence on subliminal or better learnt knowledge (Lp) and increase the likelihood of negative language transfer (see Shirai, 'Conditions on Transfer').

20 Koyama, op. cit.; Shirahata, 'Seijin dai ni gengo'; Shirahata, 'Rentai shūshoku kōzō'; Shirahata, 'Yōji no dai ni gengo.'

21 Clancy, op. cit.; Murasugi, op. cit.; Murasugi and Hashimoto, op. cit.; Nagano, op. cit.
} 
of the following: '1) intra-group homogeneity, 2) inter-group heterogeneity and 3) similarities between the native language [Lp] and interlanguage performance. ${ }^{22}$ Okuno's study did not reveal inter-group heterogeneity between the Chinese and English groups, and did not demonstrate negative language transfer despite the fact that Chinese also utilises de following an adjective (see Table 3). Moreover, the effectiveness of the IRJT was not clear. Lastly, Okuno and Sakoda's studies were conducted in Japan with subjects who had lived in Japan for at least six months at the time of participation and had no other prior language knowledge apart from their mother-tongue and Japanese.

This study firstly aimed to investigate the misuse of no by Chinese, Korean and English L1 learners of Japanese to determine whether negative language transfer underlies the misuse and to assess whether the misuse is prominent in only the verb category by replicating Okuno's study using a sample from outside of Japan. Secondly, an additional group of Japanese L1 speakers was added to offer insights regarding the learners of Japanese and to identify potential inadequacies of the IRJT. The major difference between this study and Okuno's is that the participants in this study are studying at an Australian university using English. This means Chinese and Korean L1 learners in the new study are also functionally fluent in English. Lastly, the results from the current study will be contrasted with Okuno's, with special consideration for the English knowledge of the participants.

Based on the above aims, the research questions are as follows:

1. Does the advanced Chinese L1 learner group perform significantly more poorly in recognising misuse of no in the four categories (true adjective, noun-adjective, verbal and noun-modifying phrase), compared with the advanced Korean L1 and English L1 groups?

2. If there is observed poorer performance, is this due to the participants not having acquired and/or being unable to apply the relevant grammar knowledge to no?

3. Are these results different from the results of Okuno?

4. Are there differences in the performance of the three L1 groups when compared with the group of Japanese native speakers?

22 Ellis, op. cit., p. 352. 
If the Chinese L1 group does perform significantly worse than the Korean and English L1 groups on the IRJT without differences in the WT, then misuse may be attributable to negative language transfer. If comparatively poorer performances in Chinese L1 groups are only found in the verbal phrase, as suggested by Okuno's study, then negative language transfer may be specific only to errors in one category despite the rules relating to the use of $d e$ in Chinese. If no differences are found, this may indicate that English as a second language has impacted on Japanese-language acquisition and/or production.

\section{Research Methodology}

In contrast to the mainly qualitative approach of past research on this topic, this study employed a quantitative approach based on Okuno's second study. Ethics approval for this study was granted by the University of New South Wales Ethics Committee in November 2011.

\section{Design}

This study employed a 4x4 design. The independent variables are the subjects' first language (i.e. Chinese, Korean, English or Japanese) and the four categories of misuse of no: the omission of no after nouns (noun-modifying phrase), the addition of no after a true adjective phrase, the addition of no after verbs (verbal phrase) and substitution of no for na in noun-adjective phrases. The dependent variables are the number of correct uses and the number of misuses of no correctly judged in the IRJT and WT.

\section{Participants}

Twenty-eight current students and graduates of the University of New South Wales and University of Sydney either enrolled in, or having completed, advanced-level Japanese courses equivalent to Level N2 or above of the Japanese Language Proficiency Test ${ }^{23}$ were recruited to participate in this study. The level of proficiency was confirmed by the Simple Performance-Oriented Test (SPOT). ${ }^{24}$ The participants were Chinese L1 learners (9), Korean L1 learners (5), English L1 learners (9) and Japanese L1 learners (5).

23 For information on the Japanese Language Proficiency Test, see http://www.jlpt.jp/e/about/index.html.

24 See Ford-Niwa et al., 'Bunpō kōmoku chōtō nōryoku to onsei kankyō’; Hashimoto, 'Nihongo gakusei no SPOT tokuten'; Kobayashi et al., 'Nihongo nōryoku kan’i shiken (SPOT) no tokuten bunpūkeikō'. 


\section{Instruments}

Three testing instruments and a questionnaire were employed to conduct this study. SPOT is a simple listening test that requires participants to fill in the missing hiragana character, as shown in Example $1 .^{25}$

\section{Example 1.}

たなか

田中さんはもうすぐ来る（）ずです。

Tanaka san wa mou sugu kuru ( ) zu desu

Lit. “ Tanaka Mr [particle] very soon come (shou)ld is”

SPOT is comprised of ten practice and 60 test questions. Furigana was supplied for all kanji characters. ${ }^{26}$

A second listening test, the main instrument for measuring the recognition of no, is Okuno's IRJT. ${ }^{27}$ As discussed above, the IRJT aims to assess the subjects' subliminal or better-learnt Japanese-language knowledge through their ability to instantaneously respond to auditory cues in a restricted time frame. ${ }^{28}$

The IRJT consists of two sections with 40 questions each, totalling 80 questions. Twenty-nine questions were manipulated to contain no misuse and 32 questions contained correct use. The 29 manipulated questions and the 32 correct-use questions were further divided into the four categories of true adjective, noun-adjective, verb and noun-modifying phrases, as shown in Table 4. The remaining 19 questions were fillers that contained misuse and correct use of other non-no grammar.

Table 4. The Number of Questions per Category in the IRJT

\begin{tabular}{|c|c|c|c|c|c|}
\hline Questions & $\begin{array}{l}\text { True adjective } \\
\text { phrase }\end{array}$ & $\begin{array}{l}\text { Noun- } \\
\text { adjective } \\
\text { phrase }\end{array}$ & Verbal phrase & $\begin{array}{l}\text { Noun- } \\
\text { modifying } \\
\text { phrase }\end{array}$ & Total \\
\hline Misuse of no & 8 & 5 & 11 & 5 & 29 \\
\hline Correct use of no & 7 & 5 & 10 & 10 & 32 \\
\hline
\end{tabular}

25 SPOT was employed with approval of the developers.

26 Version 3 of SPOT was used.

27 Developed by Okuno, op. cit.

28 For more information on IRJT, see ibid., p. 100. 
Below are examples of misuse and correct use in the above four categories.

Example 2. Misuse: True adjective phrase

か彼の方 が、正しいのような気がしてきた。

Kare no hou ga, tadashii no you na ki ga shitekita.

$$
\text { Answer: } \mathrm{X}
$$

Example 3. Misuse: Noun-adjective phrase

れいせい こうどう あんしん

冷静の行動をみて、安心しました。

Reisei no kōdō o mite, anshin shimashita.

$\uparrow$

Answer: な $(n a)$

Example 4. Misuse: Verbal phrase

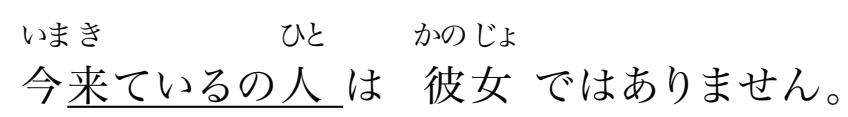

Ima kiteiru no hito wa kanojo dewa arimasen.

$$
\text { Answer: } \mathbf{X}
$$

Example 5. Misuse: Noun-modifying phrase

にほん がいこくじんともだち

日本にきて、外国人友達をたくさんつくりました。

Nihon ni kite, gaikokujin tomodachi o takusan tsukurimashita.

$$
\text { Answer: の (no) }
$$

Example 6. Correct use: True adjective phrase

がいこく あたらしごと抏

外国で、新しい仕事をみつけようと思います。

Gaikoku de, atarashii shigoto o mitsukeyō to omoimasu.

Answer: Correct 
Example 7. Correct use: Noun-adjective phrase

$\begin{array}{lll}\text { ちゅうごくうがつ } & \text { とくべつ たもの } \\ \text { 中国では、これは正月の } & \text { 特別な食べ物です。 }\end{array}$

Chuugoku de wa, kore wa shōgatsu no tokubetsu na tabemono desu.

Answer: Correct

Example 8. Correct use: Verbal phrase

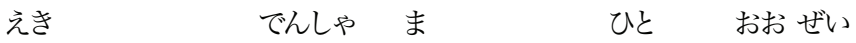

駅のホームで電車を待っている人 が大 勢います。

Eki no hōmu de densha o matteiru hito ga ōzei imasu.

Answer: Correct

Example 9. Correct use: Noun-modifying phrase

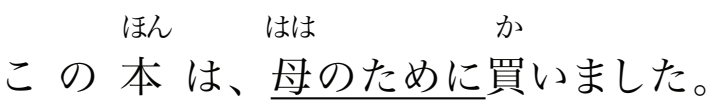

Kono hon wa, haha no tame ni kaimashita.

Answer: Correct

The target section requiring judgement is not printed on the test page, as shown in Example 10, to increase the dependence on subliminal knowledge.

\section{Example 10.}

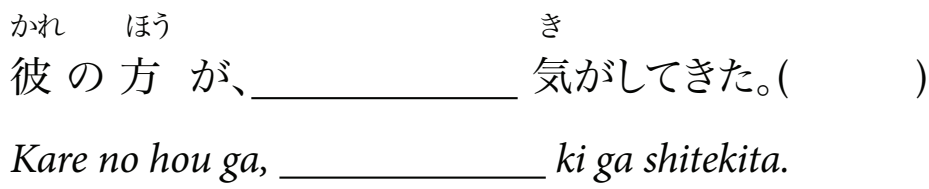

The audio recording was produced by recording a native Japanese speaker reading each question aloud at the average speed of speech to imitate natural conversations amongst native Japanese speakers. The recordings were edited to contain a half-second pause between the question number and the question, three seconds between each question and five seconds after ten questions for page-flipping time, as in the original study. Identical to the original study, a ten-second segment of Pachelbel's Canon was inserted midway through each section to allow for a short rest.

The section order was counterbalanced; that is, half of the participants received section one first and half received section two first, as in the original study. Participants were instructed to mark grammatically incorrect sentences with $\times$ and correct sentences with $\bigcirc$. One point was given per correct answer. 
The last testing instrument was the WT. The participants were given 80 questions on paper without any audio cues, relying only on visual cues to increase the use of conscious language knowledge for grammar judgements. The questions were presented without missing parts, as shown below.

\section{Example 11.}

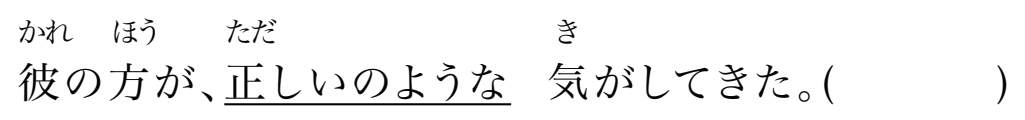

Kare no hou ga, tadashii no you na ki ga shitekita.

Again, participants were instructed to mark grammatically incorrect sentences with $\times$ and correct sentences with $\bigcirc$. Questions marked as incorrect also required participants to make a correction. One point was given for each correctly answered question with the appropriate corrections made when necessary, as shown in Example 12.

\section{Example 12.}

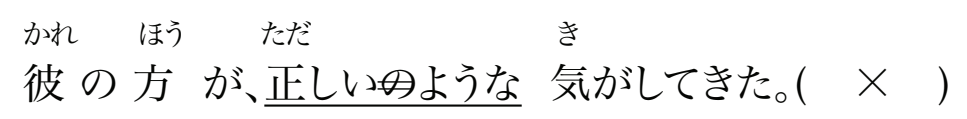

Kare no hou ga, tadashii no you na ki ga shitekita.

The questionnaire was created to gather subjects' language background, their history of Japanese language studies, and the frequency and level of use of their acquired languages. Written permission was obtained from participants via a signed consent form.

\section{Procedure}

Data collection was conducted in the following order: 1) consent form; 2) SPOT; 3) IRJT; 4) WT; 5) questionnaire.

Firstly, participants read and signed the consent form to participate in the study and were subsequently assigned the SPOT. Instructions were provided both in Japanese and English on the paper, and explained verbally either in English or Japanese according to their preference. Practice questions were played to allow participants to adjust to the audio and the format of the test. The test was conducted with no pauses once the participants understood the instructions and test procedures. The SPOT test took six minutes.

The IRJT was assigned after a short break following the completion of the SPOT. This test was administered in a similar manner to the above, using instructions written in 
Japanese and English and verbal explanations in either English or Japanese. This test took approximately 15 minutes. After the completion of the IRJT, the WT was assigned. English and Japanese written instructions were provided on paper, and verbal explanations were also provided in either English or Japanese, along with explanations of the examples. The WT is a self-paced test, and participants took between five minutes and one hour to complete the test. Lastly, the questionnaire was completed at the conclusion of the WT.

\section{Results}

\section{Data Analysis}

The results obtained were analysed using the statistical package SPSS 20. As the number of questions varied per category, a score out of five was calculated before analysis as a comparison benchmark.

Multiple t-tests were used as the method of analysis due to the small sample size, in conjunction with one-way ANOVA F-tests to control for error rates. Only results with a controlled error rate of $p<.05$ were analysed using t-tests. The results with the controlled error rate were the verbal category misuse recognition score $(F(1,20)=7.28, p<.005)$, and the noun-modifying phrase misuse recognition in the $\operatorname{IRJT}(F(1,24)=3.10, p<.05)$.

Furthermore, t-tests were performed for within-group comparisons of misuse and correct use in each category between the IRJT and the WT, and for comparisons of misuse and correct-use recognition in the four categories of the IRJT and the WT.

\section{Between-Group Comparisons}

The analysis found significant differences in the correct recognition of no misuse in the verbal phrase category in the IRJT between the Chinese and Korean L1 groups $(t(12)=$ $-2.36, p<.05)$, Chinese and English L1 groups $(t(16)=-2.70, p<.05)$ and the Chinese and Japanese L1 groups $(t(12)=-5.46, p<.001)$, whereby the Chinese L1 group performed significantly worse. The English group performed significantly worse than the Japanese $(t(12)=-2.25, p<.05)$. There were no significant differences in the case of Korean and English, and Korean and Japanese group comparisons (see Figure 1).

There were also significant differences in noun-modifying phrase category misuse recognition performance in the IRJT, whereby the Chinese group $(t(12)=-3.00, p<.05)$ and 
the English group $(t(12)=-3.10, p<.01)$ performed significantly worse than the Japanese group, whilst the Korean group did not perform statistically differently. ${ }^{29}$

Figure 1. The mean scores of correctly recognised misuse of no per category for the four L1 groups in the IRJT

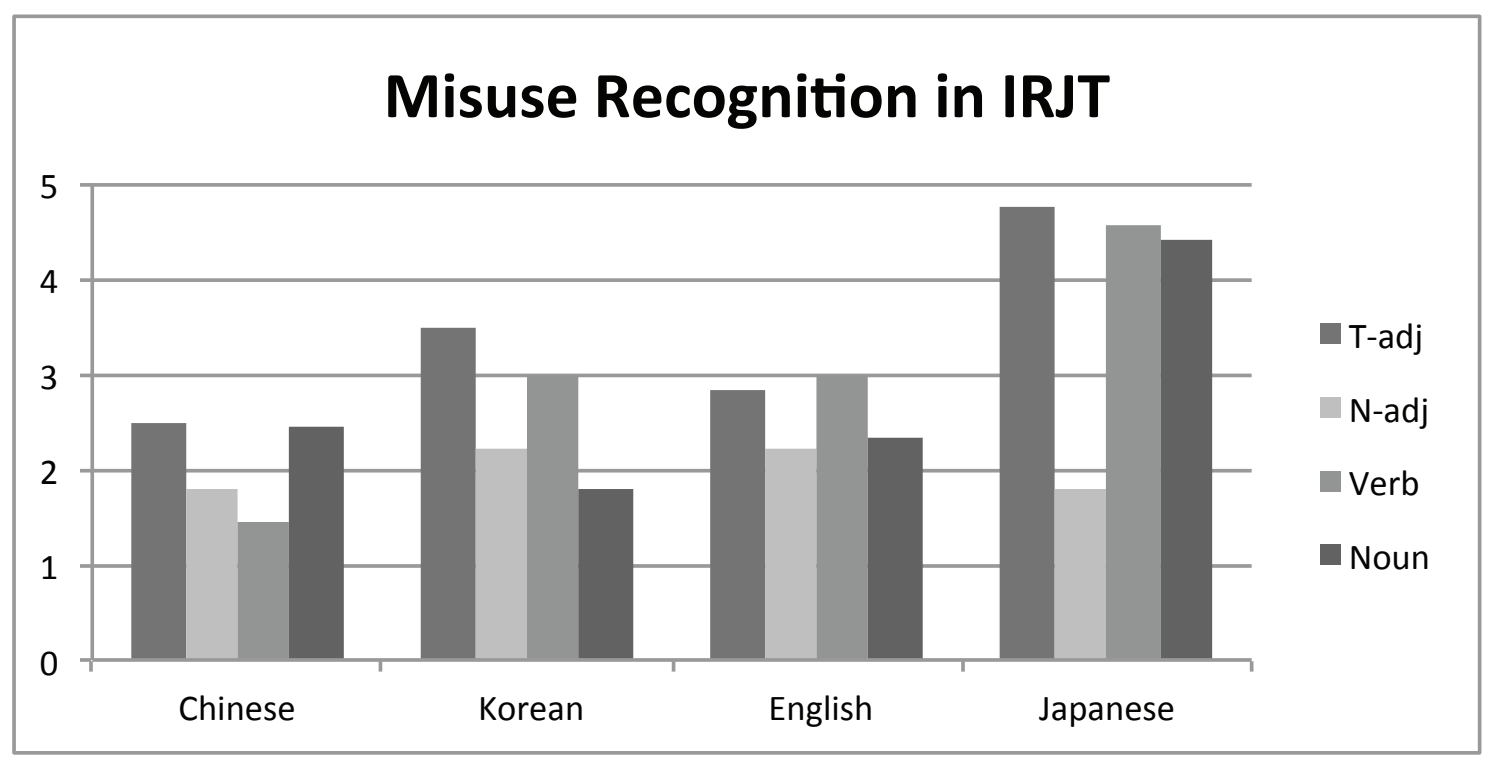

Figure 2. The mean scores of correctly recognised correct use of no per category for the four L1 groups in the IRJT

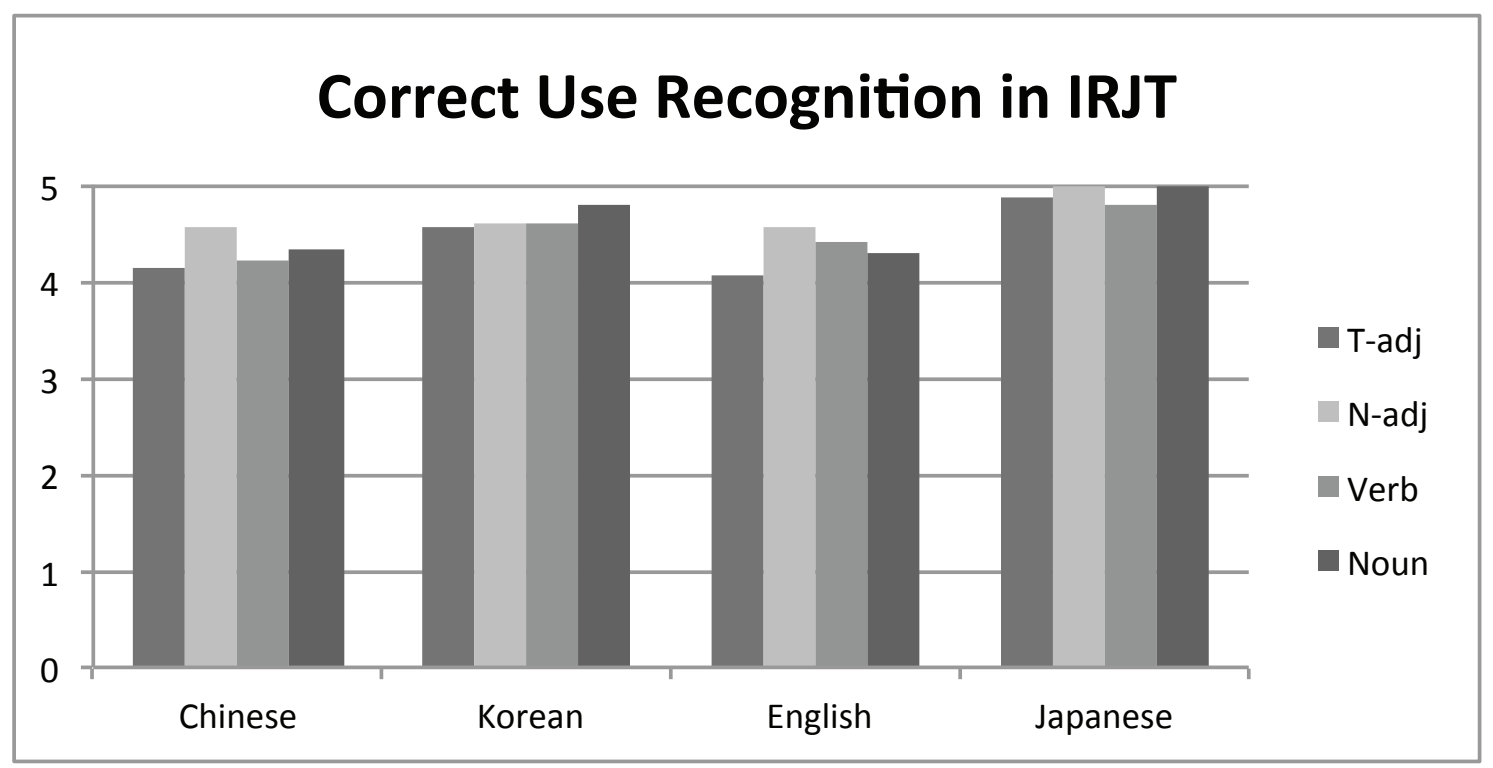

29 All standard deviations are as shown in Tables 5-8, overleaf 
Figure 3. The mean scores of correctly recognised misuse of no per category for the four L1 groups in the WT

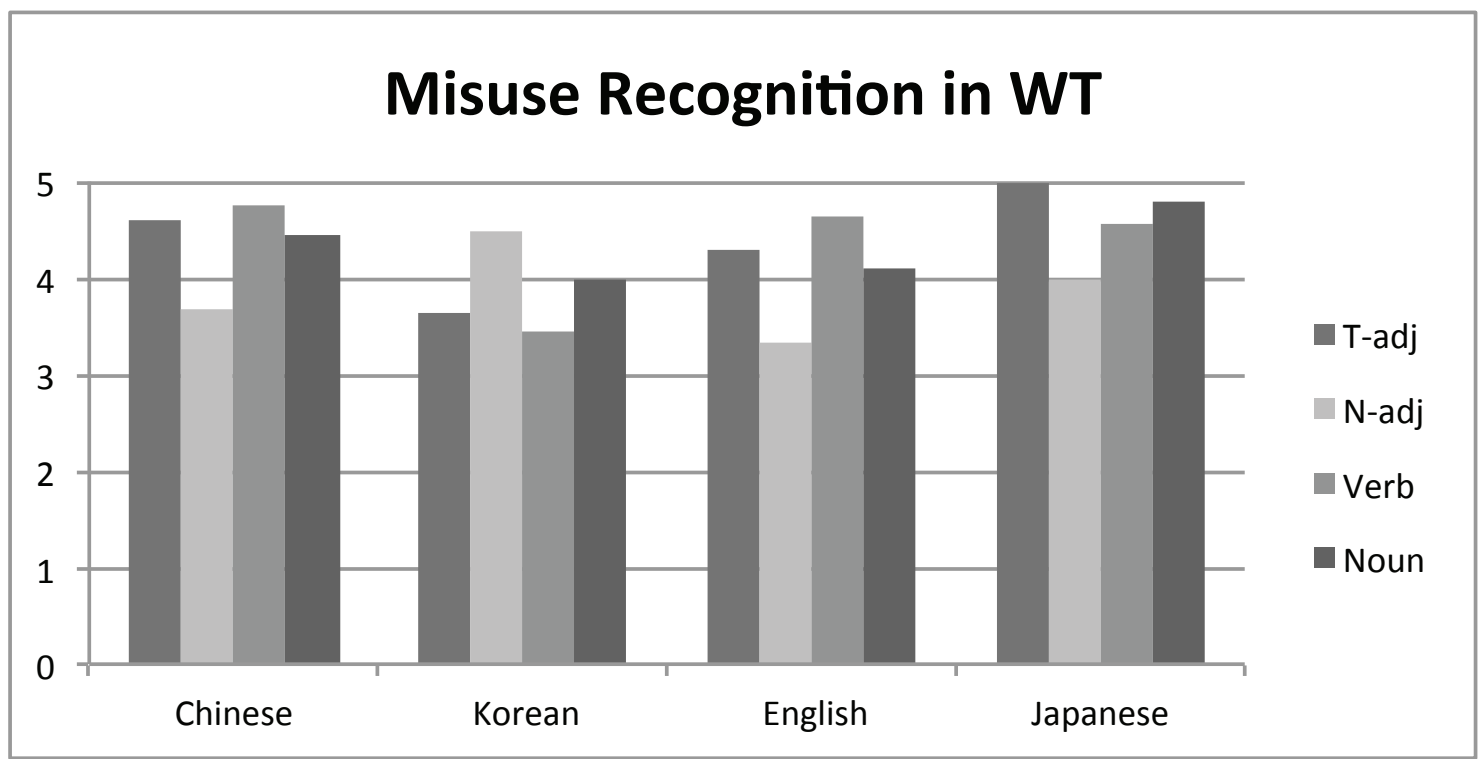

Figure 4. The mean scores of correctly recognised correct use per category for the four L1 groups in the WT

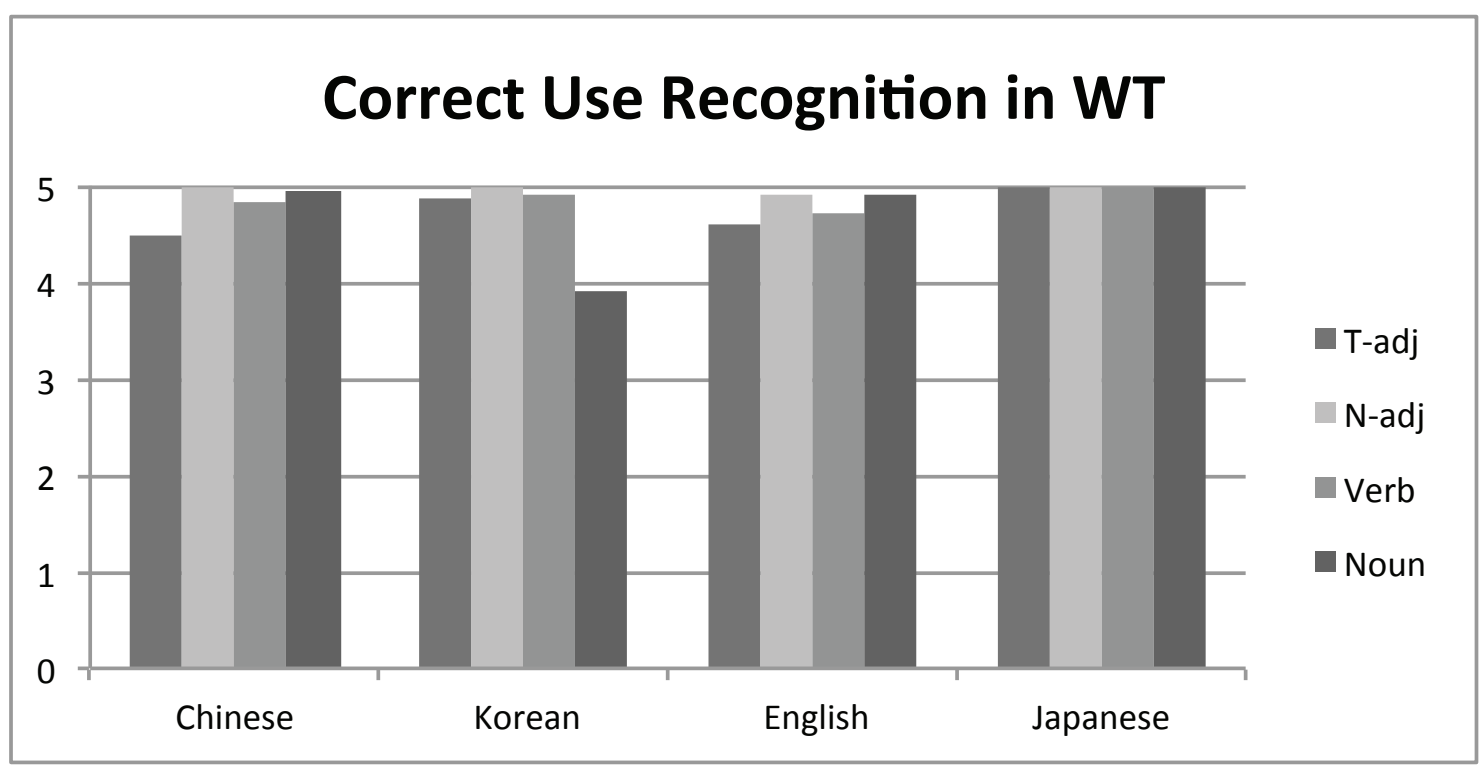


Table 5. Mean score and standard deviation per condition for misuse recognition in the IRJT

\begin{tabular}{|lllll|}
\hline $\mathbf{M}(\mathrm{SD})$ & True adjective & Noun-adjective & Verb & Noun \\
\hline Chinese & $2.50(1.53)$ & $1.78(1.64)$ & $1.46(1.01)$ & $2.44(1.81)$ \\
Korean & $3.50(1.91)$ & $2.20(1.10)$ & $3.00(1.42)$ & $1.80(1.48)$ \\
English & $2.85(1.40)$ & $2.22(0.67)$ & $2.98(1.35)$ & $2.33(1.41)$ \\
Japanese & $4.75(0.56)$ & $1.80(0.84)$ & $4.55(1.02)$ & $4.40(0.55)$ \\
\hline
\end{tabular}

Table 6. Mean score and standard deviation per condition for correct use recognition in the IRJT

\begin{tabular}{|lllll|}
\hline M (SD) & True adjective & Noun-adjective & Verb & Noun \\
\hline Chinese & $4.13(0.48)$ & $4.56(0.53)$ & $4.22(0.83)$ & $4.33(0.50)$ \\
Korean & $4.57(0.39)$ & $4.60(0.55)$ & $4.60(0.65)$ & $4.80(0.27)$ \\
English & $4.05(0.80)$ & $4.56(0.53)$ & $4.39(0.74)$ & $4.28(0.71)$ \\
Japanese & $4.86(0.32)$ & $5.00(0.00)$ & $4.80(0.45)$ & $5.00(0.00)$ \\
\hline
\end{tabular}

Table 7. Mean score and standard deviation per condition for misuse recognition in the WT

\begin{tabular}{|lllll|}
\hline M (SD) & True adjective & Noun-adjective & Verb & Noun \\
\hline Chinese & $4.58(0.70)$ & $3.67(0.87)$ & $4.75(0.33)$ & $4.44(0.73)$ \\
Korean & $3.63(2.09)$ & $4.50(0.58)$ & $3.45(1.97)$ & $4.00(1.41)$ \\
English & $4.31(0.79)$ & $3.33(1.22)$ & $4.65(0.50)$ & $4.11(1.27)$ \\
Japanese & $5.00(0.00)$ & $4.00(0.00)$ & $4.55(0.32)$ & $4.80(0.45)$ \\
\hline
\end{tabular}

Table 8. Mean score and standard deviation per condition for correct use recognition in the WT

\begin{tabular}{|lllll|}
\hline $\mathbf{M}(\mathrm{SD})$ & True adjective & Noun-adjective & Verb & Noun \\
\hline Chinese & $4.84(0.31)$ & $5.00(0.00)$ & $4.83(0.35)$ & $4.94(0.17)$ \\
Korean & $4.86(0.32)$ & $5.00(0.00)$ & $4.90(0.22)$ & $3.90(2.19)$ \\
English & $4.60(0.52)$ & $4.89(0.33)$ & $4.72(0.36)$ & $4.89(0.22)$ \\
Japanese & $5.00(0.00)$ & $5.00(0.00)$ & $5.00(0.00)$ & $5.00(0.00)$ \\
\hline
\end{tabular}




\section{Within-Group Comparisons}

The Chinese group $(t(8)=-8.89, p<.001)$ and the English group $(t(8)=-4.32, p<.005)$ performed significantly worse in verbal phrase category misuse recognition in the IRJT than the WT. In noun-modifying phrase category misuse recognition, Chinese $(t(8)=$ $-3.80, p<.005)$ and English $(t(8)=-2.35, p<.05)$ L1 groups performed significantly worse in the IRJT than the WT. Only noun-adjective phrase category misuse recognition was significantly poorer in the Japanese group $(t(4)=-5.88, p<.005)$ in the IRJT than the WT (see Figures 1 and 3). No difference was found for correct-use recognition in the IRJT and WT (see Figures 2 and 4).

Comparing recognition of misuse and correct use in the IRJT, the Chinese group performed significantly poorer in misuse recognition than correct-use recognition in the verb $(t(8)=-7.07, p<.001)$ and noun $(t(8)=-2.98, p<.05)$ categories. Similarly, the English group performed significantly worse in misuse recognition in the verb $(t(8)=$ -3.32, $p<.05)$ and noun categories $(t(8)=-4.45, p<.005)$. Lastly, significantly poorer performances were found for the Japanese group in the noun-adjective category of misuse recognition in the IRJT $(t(4)=-8.55, p<.005)$ (see Figures 1 and 2 ). No differences were found in misuse and correct-use recognition in the WT (see Figures 3 and 4).

\section{Discussion}

This study aimed to provide a better understanding of the misuse of no and the underlying cause by replicating Okuno's quantitative study. Investigations were conducted by examining Chinese, Korean and English L1 learners of Japanese in Sydney, Australia. A Japanese L1 group was added to provide new insights into the study.

The main findings of the current study are summarised as follows:

1. Poorer performances were found in the Chinese L1 learner group relative to their Korean and English L1 counterparts in verb-category misuse recognition in the IRJT. However, Chinese L1 learners performed better in verb-category correct-use recognition in the IRJT and misuse recognition in the WT than in misuse recognition in the verb category in the IRJT.

2. Chinese and English L1 learners performed relatively worse than Japanese L1 speakers only in noun-modifying phrase misuse recognition in the IRJT. There was no difference found in correct-use recognition in the IRJT and the WT. 
3. The Japanese L1 group performed significantly worse in misuse recognition in the noun-adjective category than in correct-use recognition in the IRJT. This performance was also better than the misuse recognition in the WT.

The poorer performances of Chinese L1 learners relative to their Korean and English L1 counterparts in verb-category misuse recognition in the IRJT is not attributable to confounding variables, for example, having not (correctly) acquired relevant grammar knowledge, or not having other general skills that may enable recognition of misuse. This is shown by their relatively better performance in verbal-phrase misuse recognition in the WT and correct-use recognition in the IRJT, which demonstrates capabilities similar to those of the Korean and English L1 learners. These results were in line with Okuno's study, except that the English L1 learners also performed better than the Chinese L1 group. The differences may be an indicator for negative language transfer of prior knowledge of $d e$. As indicated by Okuno (see Table 3), negative language transfer associated with the Chinese $d e$ is applicable not only in the verbal phrase but also the adjectival phrase category.

Based on this, negative language transfer should also appear in the adjective categories; however, it was neither found in the original nor the current study. In fact, in contrast with the verbal phrases, $d e$ is not compulsory in adjectival phrases in Chinese, a fact which was not specified by Okuno. While on one hand, adjectival phrases such as 美丽的人 (mei li de ren; a beautiful person) or 很小的狗 (hen xiao de gou; a very small dog) may utilise de; others do not, for example, 小狗 (xiao gou; a small dog). ${ }^{30}$ In other words, knowledge of de may not have been 'transferred' in adjective categories in a similar fashion to that of the verb category. This can explain why misuse remained only in the verb category even after the Chinese L1 learners had reached an advanced level of proficiency.

Although the results suggest negative language transfer at work, there are alternative explanations that may also account for the relatively poor performance of the Chinese L1 learners. Firstly, as mentioned earlier, misuse of no is common in learners at the intermediate proficiency level, irrespective of their first language. However, as learners advance to higher proficiency levels, the observed misuse declines. The intermediate proficiency level may be considered as the developmental stage, where learners are in the process of acquiring the grammar of no, and the decline of misuse to almost zero at higher proficiency levels marks the completion of acquisition. Conflicting features between the native language (Lp) and the target language (TL) may potentially hinder development. ${ }^{31}$ Thus, relative to other learners without the conflicting Lp-TL feature,

30 Other adjectival phrase examples without de include 黑发 (hei fa; black hair), 懒人 (lan ren; a lazy person), 好书 (hao shu; good book).

31 Yamaoka, Dai ni gengo shūtoku kenkyū. 
the learners with a conflicting Lp-TL feature may not necessarily complete the acquisition at the equivalent proficiency level. The Chinese L1 learners may have been an example of this. If this is true, then inter-group heterogeneity ${ }^{32}$ as a proposed criterion essential to the assessment of negative language transfer should be revised.

Secondly, due to the nature of the IRJT and WT, different cognitive processes are required to complete these tests. The WT, which offers sufficient thinking time, relies on conscious knowledge and allows for logical thinking. On the other hand, the IRJT demands instantaneous responses, and has a high dependency on automatisation or automatised knowledge. Automatisation refers to rapid and attention-free processing, which is achieved after much practice. ${ }^{33}$ The poorer performance in verb category misuse recognition in the Chinese L1 group, which was found in the IRJT but not in the WT, may suggest that the acquired grammatical knowledge of no had not yet been automatised. As a result, its application requires attention which is not achievable in the limited time frame offered in the IRJT. Furthermore, the conflicting Lp-TL feature in only the verb category may have delayed the process of automatisation, thus poorer performance has only been observed in the one category.

In short, although at a glance the results suggest negative language transfer, as the foundation of the assessment is not strong, other factors may have potentially impacted the results. Thus, this study can only argue for a higher possibility of negative language transfer as the underlying phenomenon responsible for misuse. Further research is needed to clarify the causal relationship between knowledge of the Chinese de and the observed poorer performance of the Chinese L1 learners in recognising misuse in the verbal-phrase category.

Interestingly, if it is negative language transfer at work, then the consistency found in results from the samples of Chinese L1 Japanese-learning populations in Japan and Australia suggest that English as a second language had no effect on their performance. This is possibly because of the closer perceived language distance between Chinese and Japanese than English and Japanese. The closer the Lp knowledge is perceived to be to that of the TL, the more likely it is to be transferred. ${ }^{34}$ As a result, the less-close English Lp may not have affected the Chinese L1 learners' judgements of misuse. However, the current study did not measure the perceived language distance in participants, thus further research is necessary to confirm this.

32 Ellis, op. cit.

33 Anderson and Lebiere, The Atomic Components of Thought, p. 5.

34 Ahukana et al., 'Inter- and Intra-lingual Interference Effects in Learning a Third Language'; Ellis, op. cit.; Ringbom, The Role of the First Language in Foreign Language Learning. 
Overall, the Japanese L1 group demonstrated better performance in comparison to the three groups of learners of Japanese. In particular, statistically better performances were found in verb and noun-modifying phrase misuse recognition in the IRJT. However, no differences were found between the performances of the Japanese L1 group and the Korean L1 group. This offers a small indication of the performance differences between the three L1 groups of learners, whereby Korean L1 learners demonstrate more outstanding language capabilities than others at the advanced level of proficiency.

The Japanese L1 group exhibited interesting results in the noun-adjective category. They performed significantly worse in misuse recognition in the IRJT than in correctuse recognition, as well as when compared to misuse recognition in the WT. It is also noteworthy that the Japanese L1 group's performance in the noun-adjective category was worse than those of the English L1 and Korean L1 groups in the IRJT on misuse recognition, although the differences were not statistically significant. If correctly used, noun adjectives are followed by na in modifying nouns, not no. Although the two differ only by a vowel, native Japanese speakers are capable of differentiating the sounds. ${ }^{35}$

However, Japanese native speakers demonstrated an apparent difficulty in using the $n a$ and the no correctly, possibly due to dual functions of certain noun-adjectives. ${ }^{36}$ For example, although 特別な (tokubetsu na; special) is a noun-adjective and takes up the na, it can also function as a noun; that is, 特別の (tokubetsu no) where no is attached. Furthermore, 元気な (genki na; physically healthy) and its antonym 病気の (byōki no; being ill) contain a semantic contrast, where one is a noun-adjective and the other a noun, respectively. Noun-adjectives, as the label suggests, are adjectives that can function like nouns and adjectives. Thus, the necessity of determining whether the vocabulary is a noun-adjective or noun, and if a noun-adjective, whether it takes na or no, can complicate matters.

Having a more complete knowledge of vocabulary could have caused some confusion in the Japanese L1 group. While learners of Japanese may have access to only the adjective function of a noun-adjective, for example, 特別な (tokubetsu na), the Japanese L1 group would also have access to the noun function of the same word. Furthermore, Japanese L1 speakers were required to make this extra decision in the time the audio produces the no, that is, in approximately 0.074 seconds. ${ }^{37}$ Although Japanese L1 speakers are noted to have difficulty in distinguishing correct and incorrect uses of na and no in the case of noun-adjectives, ${ }^{38}$ no empirical investigation has been conducted on this so far. Thus, these results provide some empirical evidence for this phenomenon.

\footnotetext{
35 For example, they have no difficulty in differentiating なる (naru; to become) and のる (noru; to get into a vehicle or form of transport).

36 Kinoshita-Thomson, personal communication.

37 Calculated by dividing the number of phonemes in a question by the audio length.

38 Kinoshita-Thomson, personal communication.
} 


\section{Limitations}

There are a number of limitations to this study. First, the small sample size is insufficient for quantitative analysis and for making reliable inferences. Additionally, the recruitment criteria recruited subjects possessing the language knowledge of interest, however, it did not rule out those who may have other additional language knowledge that may affect the results; for example, one English L1 participant reported knowing some Korean and a little Chinese on top of Japanese and English. This study did not control for participants' fourth or further language knowledge. Additional Lps may have potentially impacted on the results. ${ }^{39}$ Furthermore, negative language transfer detection and attribution becomes more difficult in the context of multilingual participants. ${ }^{40}$ Thus, strategies to account for additional languages would be necessary in future studies.

Secondly, although this was a good initial attempt at empirically investigating no misuse, the validity and reliability of the main testing instrument, the IRJT, which was employed to measure the negative language transfer, has yet to be verified. One main limitation of this test is that it does not allow for the pinpointing of errors. Simply marking a sentence as incorrect does not confirm that participants are correctly recognising misuses of no as incorrect; thus, inferences that can be made from the results are restricted. In addition, difficulty in recognising misuse (speech recognition) does not necessarily indicate that the participants produce the error themselves (speech production).

\section{Conclusion}

As there were no apparent problems with the understanding and application of the relevant grammar knowledge about the Japanese noun modifier no (Research Question 2 ), the statistically significant misuse recognition difficulty for the verb category observed in the advanced Chinese L1 participants, in comparison to their Korean and English counterparts, suggests that negative language transfer underlies the misuse (Research Question 1). These results were similar to those of Okuno's study, with the exception that in this study, the English L1 group also performed significantly better than the Chinese in the verbal category of misuse recognition in the IRJT (Research Question 3). Lastly, although the Japanese L1 group provided minimal insight into the performance of the other L1 groups, it provided some empirical evidence relating to the confusion of na and no attached to noun-adjectives in Japanese native speakers (Research Question 4). 
Future research may take into consideration the limitations of the IRJT and employ additional components to overcome them, such as requiring participants to provide verbal justification for judging sentences as grammatically incorrect between test questions during the test. An alternative may be measuring and comparing the reaction time (RT) needed to judge the misuse and correct use of no. RT has been employed as a fairly accurate measurement of cognitive processes in a range of publications. ${ }^{41}$ Negative language transfer can also be more accurately examined if the sentences are presented on screen and the no alone is underlined for determination of grammaticality. Any difference in the RT found between the Chinese and other L1 groups in the verb category will offer more concrete empirical evidence. This would in turn reduce the cognitive load on Chinese L1 learners in listening comprehension tests. It may also be necessary to collect conversation data to confirm misuse production by participants. Future research should also incorporate investigations to differentiate negative language transfer from developmental errors; that is, errors made due to incomplete acquisition of the correct use of no in the verbal-phrase category for Chinese L1 speakers.

As there are millions of Japanese learners across the world, it is quite important to have a thorough understanding of the effects of prior language on the learning of Japanese as a foreign language. In addressing the matter of negative language transfer, teachers of foreign languages can employ strategies to overcome the effects and promote more efficient learning. Furthermore, results from Japanese second-language acquisition studies may provide insights into phenomena that can be generalised to the acquisition of other second languages.

41 Coyne et al., 'The Effects of Viewing Physical and Relational Aggression in the Media'; Koch et al., 'Chunking in Task Sequence Modulates Task Inhibition'; MacDonald et al., 'Performance Variability is Related to Change in Cognition.' 


\section{Reference List}

Ahukana, J., Lund, N., and Gentile, J. R., 'Inter- and Intra-lingual Interference Effects in Learning a Third Language', Modern Language Journal, vol. 65 (1981), pp. 281-287.

Anderson, J. R., and Lebiere, C., The Atomic Components of Thought (Mahwah, New Jersey: Erlbaum, 1998).

Clancy, P. M., 'The Acquisition of Japanese', in Slobin, I. D. (ed.), The Cross Linguistic Study of Language Acquisition (New Jersey: Lawrence Erlbaum Associates, 1985), pp. 373-524.

Coyne, S. M. et al., 'The Effects of Viewing Physical and Relational Aggression in the Media: Evidence for a Cross-over Effect', Journal of Experimental Social Psychology, vol. 44, no. 6 (2008), pp. 1551-1554.

Ellis, R., The Study of Second Language Acquisition (2nd ed.) (Oxford: Oxford University Press, 2008).

Ford-Niwa, J. et al., 'Bunpō kōmoku chōtō nōryoku to onsei kankyō-SPOT (Simple Performance-Oriented Test) no kūran ichi ni kansuru一-kōsatsu’ [文法項目聴東能力と音声環境一SPOT (Simple Performance-Oriented Test）の空欄位置に関する一考察], Tsukuba daigaku ryūgakusei sentā nihongo kyōiku ronshū [筑波大学留 学生センター日本語教育論集], vol. 11 (1996), pp. 201-211.

Hashimoto, Y., 'Nihongo gakusei no SPOT tokuten to kōsu seiseki to no kankei-meruborun daigaku no baai' [日本 語学生のSPOT得点とコース成績との関係一メルボルン大学の場合], Tsukuba daigaku ryūgakusei sentā nihongo kyōiku ronshū [筑波大学留学生センター日本語教育論集], vol. 15 (2000), pp. 87-97.

The Japan Foundation, Survey Report on Japanese-language Education Abroad 2009 (Tokyo: The Japan Foundation, 2011).

Kinoshita-Thomson, C., personal communication, 21 May 2012.

Kobayashi, N. et al., 'Nihongo nōryoku kan'i shiken (SPOT) no tokuten bunpūkeikō: Chūjōkyū muke tesuto to shokyū muke tesuto' [日本語能力簡易試験(SPOT)の得点分布傾向：中上級向けテストと初級向けテスト], Tsukuba daigaku ryūgakusei sentā nihongo kyōiku ronshū [筑波大学留学生センター日本語教育論集], vol. 10 (1995), pp. 107-119.

Koch, I. et al., 'Chunking in Task Sequence Modulates Task Inhibition', Psychological Science, vol. 17, no. 4 (2006), pp. 346-350.

Koyama, S., 'Rentai shūshoku kōzō no shūtoku ni okeru 'no' no kajō shiyō - kakujoshi kasetsu to juntai joshi kasetsu' [連体修飾構造の習得における「の」の過剰使用一格助詞仮説と準体助詞仮説], Kyushu daigaku ryūgakusei sentā kiyō [九州大学留学生セン夕ー紀要], vol. 15 (2006), pp. 41-50.

MacDonald, S. W. S. et al., 'Performance Variability is Related to Change in Cognition: Evidence from the Victoria Longitudinal Study', Psychology and Aging, vol. 18, no. 3 (2003), pp. 510-523.

Murasugi, K., Noun Phrase in Japanese and English: A Study in Syntax, Learnability and Acquisition (Ph.D. dissertation, University of Connecticut, Storrs, 1991).

Murasugi, K. and Hashimoto, T., 'Yōji ni mirareru meishiku de no nishurui no kajō seisei' [幼児に見られる名詞句で の二種類の過剰生成], in Monbukagakushō kagaku kenkyūhi hojokin kahōko kusho: fukugōdōshi to kōkōzō kōkōzō no tōgo hyōshi ni kansuru hikaku kenkyū [文部科学省科学研究費補助金成果報告書: 複合動詞と項 構造～項構造の統語表示に関する比較研究] (2002), pp. 203-232. 
Nagano, K. 'Yōji no gengo hattatsu一toku ni joshi no 'no’ no shūtoku katei ni tsuite’ [幼児の言語発達一とくに助詞の 「の」の習得過程について], in Shimada kyōju koki kinen kokubungaku ronshū [島田教授古希記念国文学論 集] (Osaka: Kansai daigaku kokubungaku kai, 1960), pp. 405-418.

Odlin, T., Language Transfer: Cross-linguistic Influence in Language Learning (Cambridge: Cambridge Press, 1989).

Okuno, Y., Dai ni gengo shūtoku katei ni okeru gengo ten’i kenkyū [第二言語習得過程における言語転移研究] (Tokyo: Kazumashobō, 2005).

Peng, F., Gaikokujin wo nayamaseru nihongo kara mita nihongo no tokuchō [外国人を悩ませる日本語からみた日本語 の特徴] (Tokyo: Bonjinsha, 2003).

Ringbom, H., The Role of the First Language in Foreign Language Learning (Clevedon: Multilingual Matters, 1987).

Sakoda, K., 'Dai ni gengo shūtoku ni yoru 'no’ no fuka ni kansuru goyō’ [第二言語習得による「の」の付加に関する 誤用], 'Dai ni gengo shūtoku toshite no nihongo no shūtoku ni kansuru sōgō kenkyū' Heisei 8 nendo Heisei 10 nendo: Kagaku kenkyūhi hojokin kenkyū seika hōkoku sho [第2言語習得としての日本語の習得に関する総合 研究』平成8年度～10年度 科学研究費補助金研究成果報告書] (1999), pp. 327-334.

Shirahata, T., 'Seijin dai ni gengo gakushūsha no nihongo no rentai shūshoku kōzō kakutoku katei ni okeru ayamari no bunrui’ [成人第2言語学習者の日本語の連体修飾構造獲得過程における誤りの分類], Shizuoka daigaku kyōiku gakubu kenkyu hōkoku [静岡大学教育学部研究報告], vol. 45 (1994), pp. 175-190.

Shirahata, T., 'Rentai shūshoku kōzō kakutoku katei ni okeru kasekika genshō’ [連体修飾構造獲得過程における化石 化現象], in Heisei 5 nendo nihongo kyōiku gakkai shunki taikai yokō shū [平成5年度日本語教育学会春季大 会予稿集] (Tokyo: Nihongo kyōiku gakkai, 1993b), pp. 55-59.

Shirahata, T., 'Yōji no dai ni gengo to shite no nihongo kakutoku to 'no' no kajō seisei-kankokujin yōji no jūdan kenkyū’ [幼児の第2 言語としての日本語獲得と『ノ』過剰生成〜韓国人幼児の縦断研究〜], Nihongo kyōiku gakkai [日本語教育学会], vol. 81 (1993a), pp. 104-115.

Shirai, Y., 'Conditions on Transfer: A Connectionist Approach', Issues in Applied Linguistics, vol. 3, no. 1 (1992), pp. 91-120.

Yamaoka, T., Dai ni gengo shūtoku kenkyū (Tokyo: Kirihara Yuni, 1997).

Yokoyama, M., 'Yōji no rentai shūshoku hatsuwa ni okeru joshi ‘no’ no goyō’ [幼児の連体修飾発話における助詞「ノ」 の誤用], Hattatsu shinrigaku kenkyū [発達心理学研究], vol. 1, no. 1 (1990), pp. 2-9. 